\title{
THE RELATIONSHIP BETWEEN ORGANIZATIONAL LEARNING AND FIRM PERFORMANCE: THE MEDIATING ROLES OF INNOVATION AND TQM
}

\author{
Ipek KOCOGLU \\ Salih Zeki IMAMOGLU \\ Hüseyin INCE \\ Gebze Institute of Technology, Turkey
}

\begin{abstract}
The main purpose of this study is to evince the influence of organizational learning on firm performance through the mediating roles of innovation and total quality management (TQM). The relationship is constructed based on the four dimensions of organizational learning namely; intraorganizational knowledge sharing, shared vision, commitment to learning and open mindedness and the two dimensions of firm performance explicitly; market performance and employee satisfaction. Amid in this research agenda three partial gaps have been explored: First, besides the relationship between TQM and innovation, a robust relationship of organizational learning and firm performance seem to be plausible but the gap embedded in the literature is the absence of a study examining the cumulative influence of the organizational factors which complement and enhance each other organizational learning, innovation and TQM- on the organizational performance. In doing so this study investigates the four dimensions of organizational learning mentioned previously, the five dimensions of the TQM, particularly -participation, leadership, process management, continuous improvement and customer orientation, and innovation in the context of their impact to market performance and employee satisfaction as the components of firm performance. Second, previous works have almost exclusively focused on the co-alignment between organizational learning and innovation as compelled to deliver firm performance. While the relationship between organizational learning and firm performance has been investigated there has been minimal analysis of the phenomena taking into account the role of innovation. Hence little empirical evidence has so far been offered to support the positive relationship between these strategic weapons of the organization on the performance as well as each other. Third, the paper investigates the multidimensional and contingent gradual effect of organizational learning on firm performance through the conjunctive roles of innovation and TQM without ignoring the counteraction to potential changes from a satisfactory status -quo. Concurrently, this study develops a platform through which organizational learning will shape innovation, TQM and progressively the firm performance.
\end{abstract}

\section{Keywords}

Organizational learning, innovation, total quality management, organizational performance

\section{INTRODUCTION}

"The only real security that a man can have in this world is a reserve of knowledge, experience and ability." Henry Ford's words reflect the significance of knowledge coming into prominence in an era where the speed of change exceeds the limits of human imagination. The way an individual, an organization or even a nation can create wealth and prosperity is changed through knowledge which constitutes the basis of the third industrial revolution (S.-h. Liao et al., 2008). Although different approaches are used for the examination of organizational learning construct, learning has been more recently considered from a strategic perspective as a distinction of heterogeneity among organizations and an actor enabling competitive advantage (Gomez et al.,2005). The literature suggests that firms which are able to "learn" obtain a better opportunity in sensing events and trends in the marketplace (Martinez-Costa and Jimenez-Jimenez, 2009). Since Drucker (1985) asserts knowledge as the only source of an organizations' competitive advantage; enterprises should find ways to strengthen the research and development, management and utilization of knowledge in order to cope with the challenges (S.-h. Liao et al., 2008). Contingently, the examination of knowledge management within the 
organizations has been emerged in 1990's. The theory of Nonaka proposed in 1991, suggested the "organizational knowledge creation" through the reshaping of old operational processes and the adoption of the novel ideas (S.-h. Liao et al., 2008). Rather than considering knowledge as the "hard" source of quantifiable data which could only be mechanistically processed to utilize, Nonaka presents the idea of "soft" tools to make use of such knowledge (Nonaka, 1994). The key to the holistic way of knowledge creation of Japanese firms explicitly; Honda, Sharp, NEC and Canon in Nonaka's study is the essentiality of tapping the tacit and subjective perceptions. Hence, the resource-based theory of the firm suggests that knowledge dominates other resources through its inimitability characteristic by the continuous improvement of market information processing activities faster than competitors; it provides the long term competitive advantage to firms (Martinez-Costa and Jimenez-Jimenez, 2009). The survival of the firms in knowledge-based economies is determined by the successful knowledge management. Moreover, gaining superior firm efficiency, promoting high competitive advantage, achieving outstanding organizational performance and surviving in the competitive knowledge-based markets can be obtained by organizational learning (Ussahawanitchakit, 2008).

Organizational learning is often defined in the literature as a strategy for information management consisting of systematic efforts to relocate knowledge throughout an entire organization, following Senge's (1990) Fifth Discipline (Spector and Davidsen, 2006). With the exploitation of organizational values, information processing behaviors, and organizational actions enterprises use organizational learning as a source of heterogeneity and of sustainable competitive advantage. Hereby firms need to strengthen the research and development of organizational learning, to manage it efficiently, to utilize it effectively and to acquire it continuously for the aim of distinctively meeting customer requirements and seeking market needs (Ussahawanitchakit, 2008). In this regard, organizations need to determine the factors affecting organizational learning, and the factors that are influenced by the organizational learning.

This study therefore contributes to this area by examining the relationship of organizational learning with the firm performance through the mediating roles of innovation and total quality management. This study contributes to the literature in several ways. First, this study is important when viewed in relation to today's highly competitive environment where pressures for organizations to meet multiple demands is a challenging task where several forces need to be working in collaboration to achieve a unique goal. Therefore, this study targets to determine the intra-relations of organizational learning, innovation, TQM and firm performance, and to estimate their distinct effects on organizational performance. Secondly, this study constitutes an important bridging between the areas of knowledge management, quality management, innovation management and strategic management. Strategic management focuses on the performance concept in organizations and knowledge management aims at improving the performance of enterprises together with the competitive advantage using organizational learning as a key factor. Both in academic and in professional surroundings the researches prove that learning is of essential importance for organizations (F.J. Lloréns Montes et al., 2005). An overview of the innovation literature reflects that there's a great consensus among researchers about the importance of the innovation in the achievement of high organizational performance (F.J. Lloréns Montes et al., 2005). In parallel to calls made for organizations to become innovation focused, they have also been urged to become more quality focused (Singh and Smith, 2004). From the innovation point of view, the examination of the TQM's impact on innovation is important in contributing to the development of managerial practices which can be used as a resource for determining innovation performance (Prajogo and Sohal, 2006). The awareness of the dominance of these two concepts; innovation and learning, necessitates the examination of the relationship between the two as well. Although the arguments in literature consider the positive relationship between learning and innovation there are several gaps regarding the issue. The empirical standpoint of this link is missing and innovation's mediating role in providing the organization to fit into its environment is not examined (F.J. Lloréns Montes et al., 2005). Moreover, the emergence of Total Quality Management (TQM) has been one of the major developments in management practice, which has been considered quite few in relation with organizational learning, and innovation as well as organizational performance. TQM started to be introduced in the US around 1980 with a devastating delay resulting in the domination of Japanese firms in the market. Western organization culture beginning to interrogate the reasons for the sudden drop in the market share has needed to primarily deal with deep competitive challenges encountered due to Japanese companies' successful adoption of TQM (Prajogo and Sohal, 2001). At this standpoint this study recognizes the need to acknowledge the link between Nonaka's suggestion of learning from Japanese companies in knowledge creation and management, with the successful application of TQM 
to their enterprises. TQM has been promoted as an approach to management that enables organizations to become customer (internal and external) and quality focused (Singh and Smith, 2004).

Based on an extensive review of relevant literatures on organizational learning, innovation, TQM and firm performance it is noticeable that the concepts are closely intertwined and explicitly linked. Accordingly, organizational learning is a critical strategy which organizations implement it to build high firm performance; gain outstanding competitive advantage and enhance competitiveness. Organizational learning makes these goals accessible to the enterprise by the mediating roles of innovation and TQM both on each other and on organizational learning itself. This paper explores the possibility of using organizational learning with the mediating roles of innovation and TQM as collective contribution to the firm performance. Furthermore the paper is arranged starting with the literature review of each concept; organizational learning, innovation, TQM and firm performance. Accordingly six main hypotheses are investigated and supported through the literature, in parallel with the proposed theoretical model regarding the positive inter-relationships of all the above mentioned variables. The six sets of hypotheses inspected in this study are explained in the following literature research section of the study. The proceeding section is the research methodology, and finally the article is concluded with the conclusion part.

\section{ORGANIZATIONAL LEARNING AND INNOVATION}

\section{Organizational Learning}

Learning; is at the heart of company management and has become the essence of productive activity, being a need more than a choice in today's conditions (F.J. Lloréns Montes et al., 2005). When John Dewey's definition of individual learning as "the process whereby knowledge is created through the transformation of experience creating a change in that person's behavior" is compared with that of Argyris and Schön, (1978) "organizational learning occurs when members of the organization act as a learning agent for the organization, responding to changes in the internal and external environment of the environment by detecting and correcting errors" the bridge between the individual and organizational learning becomes clear. Organizational learning shares many of the characteristics of individual learning mainly; that learning is about changes that tend to persist and measuring those changes would establish that change has occurred (Spector and Davidsen, 2006). All humans are born with the ability to learn and through it they adapt to the changing and evolving environment (S.-h. Liao et al., 2008). The learning of organizations in the study of S.-h. Liao et al. (2008) are referred to as; when the members of an organization use learning to solve a common problem that they are facing. Though, learning to achieve the organizational level crosses two stages; individual and group learning thereafter it becomes organizational. Individual learning occurs with the acquisition or creation of knowledge, group learning happens when this knowledge is transferred and disseminated and finally organizational learning is achieved with the integration and sharing of this knowledge through the organization (Gomez et al., 2005). Yet, organizational learning has a collective nature that goes beyond the individual learning of people (Gomez et al., 2005). Supporting this idea, Argyris and Schön as referred to in Baker and Sinkula's (1999) study; organizational learning occurs by detecting a mismatch of outcome to expectation, which disconfirms theory in use. When this occurs, the firm moves to error correction, which results in a change in theory in use (Baker and Sinkula, 1999). The collective action of the firm to detect the unwanted outcome and its correction implies a continuum of internal changes which in turn will lead to constant improvement and innovation (Gomez et al., 2005).

Most of the researchers describe the organizational learning process as the acquisition, interpretation, storage and implementation of new knowledge in order to improve problem solving capacities of the organization (Huber, 1991; Thomas et al., 2001; S.-h. Liao et al., 2008). Learning by an individual forms the basis of organizational learning since organizations will learn through its members and because it results from an accumulation of individual learning (S.-h. Liao et al., 2008; Calantone et al., 2002). Another view is that of Nonaka (1995) who claims that, organizational knowledge is created through the continuous interaction between tacit and explicit knowledge. Consequently, Spector and Davidsen (2006) argue the measurement and modeling of organizational learning based on a sociallysituated, information processing view of learning. Peter Senge; the writer of the seminal book The Fifth Discipline: The Art \& Practice of the Learning Organization and the founder of the Organizational Learning Center at MIT, which later became the society for Organizational Learning (1990), argues that the a group of people's desire to enhance their capacity to produce is actually the interpretation of the attempt for organizational learning (Spector and Davidsen, 2006). In view of those, every 
organization will develop the most suitable learning method according to the needs and characteristics of the organization itself (S.-h. Liao et al., 2008).

Two types of organizational learning are mainly discussed in the literature. The first is; single-loop learning (Argyris and Schön, 1978) which can be referred to, as exploitative learning (S.-h. Liao et al., 2008), or incremental learning (Miner and Mezias, 1996), or Non-Duetero characterized as passive learning (Saban et al., 2000). The single-loop learning is adaptive and takes place within the structure and processes of the learning system (Hedberg and Wolff, 2001). It is the acquisition of new behavioral capacities framed within existing insights (S.-h. Liao et al., 2008: 184). The second type of organizational learning is double-loop learning (Argyris and Schön, 1978), which can also be referred to, as radical learning (Miner and Mezias, 1996), higher level or generative learning (Sadler-Smith et al., 2001), active learning (Saban et al., 2000), or explorative learning (S.-h. Liao et al., 2008). It occurs when organizations acquire behavioral capacities that fundamentally differ from existing insights. This type of learning involves multi-stage learning based on discovery, criticism, effectiveness, variation, flexibility and innovation (S.-h. Liao et al., 2008). These views constitute the basis of organizational learning literature.

The concept of organizational learning assumes that there exists a collective desire that may be satisfied through collective action and, further, that there is a potential for collective improvement that may be attained through learning. Accordingly the four dimensions of organizational learning considered in this study are, intra-organizational knowledge sharing, shared vision, open mindedness and commitment to learning. To start with; intra-organizational knowledge sharing is the spread of knowledge and information across different departments in an organization, along with the systematic reexamination and structuring of their accumulation to serve as a source of future action (Calantone et al., 2002). Second; shared vision refers to a common direction among the organization for learning. Organizational learning requires bringing the members together around a common identity with the existence of a collective conscience that allows the firm to be seen as a system in which each element must make its own contribution (Gomez et al.,2005). Involvement of people in establishing and implementing a joint vision leads to their motivation to learn what they are held responsible of (Chermack et al., 2006). Respectively the importance of relationships based on the exchange of information is recognized through a common language favoring knowledge integration (Gomez et al.,2005). Third; for the organization to outrage among firms, it must go beyond adaptive learning and concentrate on generative learning. This requires, open mindedness in the organizational structure which is the willingness to critically evaluate the organization's operational routine and to accept new ideas (Calantone et al.,2002). In order to allow individual knowledge to be constantly renewed, widened and improved, a learning that implies open mentality towards new ideas, flexible solutions to current and future problems is required (Gomez et al., 2005). Lastly, the fourth dimension is commitment to learning which indicates the degree to which an organization values and promotes the acquisition, creation and transfer of knowledge considering learning as an important investment for survival (Calantone wt al., 2002). According to Gomez et al., (2005), commitment to learning can be achieved with the support of management. Management should encourage the employees to understand and become involved in the process of learning. It should take the responsibility to create an organization capable of regenerating itself and coping with new challenges by leading the process of change (Gomez et al., 2005). Hence commitment to learning can diffuse to the whole organization.

\section{Innovation}

Innovation allows organizations to progress parallel with the changes flourishing in the environment. It's a strategic key in responding to the new challenges of an environment full of uncertainties (F.J. Lloréns Montes et al., 2005). For an organization, innovation would denote the generation or adoption of novel ideas or behavior (S.-h. Liao et al., 2008). In the literature the idea that innovation is essential for firms' long-term success and survival constituting a competitive instrument is widely recognized (Santos-Vijande and Alvarez-Gonzalez, 2007). As it is referred in the study of Hitt et al. (1997) and Tidd (2001), innovation is defined as the doors opening to both global and international competitive advantage through: providing the marketplace with new or unique products/services; creating entry barriers that provide the necessary resources to develop innovation through learning; and creating new values that reshape the rules of competitive environment (F.J. Lloréns Montes et al., 2005). Authors reflect Nonaka and Yamanouchi's (1989) suggestions as; organizations fit to the changing conditions of the technology and the market by diversifying and adapting, and even rejuvenating or "reinventing" through innovation (Santos-Vijande and Alvarez-Gonzalez, 2007). A profound research 
on innovation literature shows that various definitions of innovation are present from different perspectives. Damanpour (1991) defines innovation as; the adoption of an internally generated or purchased device, system, policy, program, process, product, or service that is not necessarily new to the world but specifically new for that adopting organization (Prajago and Sohal, 2001). Wu et al., (2008) suggest that an innovation is defined as an idea, a product or process, or a system that is perceived to be new to an individual. Besides, there are many typologies and classifications of innovation such as; radical versus incremental, product versus process, technology versus management innovation. The most established classification of innovation distinguishes it as incremental or radical. Incremental innovative capability is defined as the capability to generate innovations that refine and reinforce existing products and services. Radical innovative capability is the capability to generate innovations that significantly transform existing products and services (Subramaniam and Youndt, 2005).

\section{The Relationship between Organizational Learning and Innovation}

Innovation is closely related to organizational learning (Chaveerug, 2008). Argyris and Schön (1978) discuss in their work that organizational learning would strengthen the innovative capability of an enterprise. Veroma (1996) propounds the idea that the innovation process involves the acquisition, dissemination and the application of new knowledge (Chaveerug, 2008). Chaveerug (2008) accordingly stresses the wide agreement in the literature on the correlation between learning and innovation capability. Moreover according to S. -h. Liao et al. (2008), innovation is the prerequisite of knowledge creation and the essential key of knowledge management, because organizations mainly learn from the innovations made or adopted. Through single and double-loop learning which forms the meta-learning process, learning of the whole organization is enhanced and this contributes to innovations (S.-h. Liao et al., 2008). Chaveerug (2008) concludes in his study that organizational learning is associated with the development of new knowledge, which is crucial for firm innovation capability and firm performance. Darroch (2005) as a result of her research states that "a firm capable in knowledge acquisition, knowledge dissemination and responsiveness to knowledge is more innovative." Most studies consider that learning injects new ideas and strengthens the creativity and the ability to discover new opportunities, so it supports the presence of innovation (F.J. Lloréns Montes et al., 2005). Most successful innovations are the result of gradual changes in concepts and methodology implemented continually over time (S.-h. Liao et al., 2008). This gradual process relies on the creation, search, acquisition and sharing of knowledge which in turn will provide organizational learning and will constitute the base for the successful innovation. In fact, as a result of the successful applications of numerous organizational learning models to some aspects of innovative processes, the new meaning of the innovation concept starts to be reshaped as the process of organizational learning by the organizations (F.J. Lloréns Montes et al., 2005). The above discussion reflects the interaction between organizational learning and innovative outcomes of an enterprise, hence, as stated in the following hypotheses.

Hypothesis 1: Organizational learning has a positive influence on innovation.

\section{ORGANIZATIONAL LEARNING AND TQM Total Quality Management}

The most influential person in the quality revolution was Dr. Edward Deming. After a special program produced in television titled "If Japan can. Why can't we?" The focus was on Deming's role on the development of Japanese quality. After that program the importance given to quality in U.S. industry increased and U.S. government recognized the influence of quality on nation's economic wealth (Samson and Terziovsky, 1999). Concurrently, TQM has moved away from being a uni-dimensional construct to being evaluated as a strategic weapon for the firms which has to be managed and implementation of which leads to a dynamic capability of the enterprises (Ortiz et al., 2006).

Among many definitions that have been suggested on TQM, the definition by the US Department of Defense suggests that; TQM utilizes both quantitative (technical) methods and human resource (behavioral) practices to improve material and service inputs, intra- and inter-organizational processes, and to sharpen the focus on meeting customers' needs (Singh and Smith, 2004). The main problem in defining TQM is the absence of a common definition in the literature. TQM concepts and practices are shaped by a number of individuals who are honored as "quality gurus" such as; Deming (1982), Feiganbaum (1983), Juran (1988), Juran and Gyrna (1993) and Crosby (1984). Commonly, TQM can be understood as a total company wide effort that includes all employees, customers and 
suppliers and that continually aims at improving the quality of products and processes to meet and even exceed the needs of the customers (Martinez-Costa and Jimenez-Jimenez, 2009). Kumar et al. (2009) refer to the definition of Pfau (1989) who describes TQM as a holistic approach to improving quality, productivity and competitiveness in the international marketplace. Another definition of TQM similar to that of Singh and Smith's (2004) is that of Yang (2005) who gives more detail by stating that TQM is an integrated management philosophy and a set of practices that emphasizes, among other things, continuous improvement, meeting customers' requirements, reducing rework, long-range thinking, increased employee involvement and team-work, process redesign, competitive benchmarking, team-based problem-solving, constant measurement of results, and closer relationships with suppliers (Kumar et al., 2009). Hence there is a systematic integration among the dimensions of the TQM leading to integral management (Ortiz et al., 2006). The dimensions of Total Quality Management are needed to be identified to facilitate accurate analysis. These dimensions are; leadership, people management, customer focus, strategic planning, information analysis, process management, performance (quality, operational and business performances) (Samson and Terziovsky, 1999; Singh and Smith, 2004; Prajogo and Sohal, 2001; Samson and Terziovsky, 1999).

Yet this study focuses on the four among the dimensions of TQM explicitly; participation which is also referred to as people management, leadership, continuous improvement, process management and customer focus. As stated in Costa et al.'s (2008)study reflecting Evand and Lindsay's (2002) definition; "focus on customers and stakeholders, participation and teamwork by everyone in the organization and a process focus supported by continuous improvement and learning". Participation indicates a decentralization of work decisions and empowerment. In parallel with the selection and training of the personnel as besides the incentive programs, the sense of equity building creates employees that are actively taking role in the quality creation, continuous improvement of processes and products (Ortiz et al., 2006). Leadership reflects management's commitment and vision towards creating a strategic resource out of quality which acts to achieve competitive advantage. The formulation of strategy and objectives to reach quality should be aligned with corporate strategy as well as organizational values in which management plays a crucial role (Ortiz et al., 2006). Additionally continuous improvement which encourages change and creative thinking in the organization structure of the work provides to creatively exceed the quality standards or usual expectations. Moreover, as argued by Prajogo and Sohal, (2001), the continuous improvement requires the standardization of the processes which produces several consequences: (a) it reduces any ambiguity in the design of tasks, which makes its innovation difficult; (b) it results in some organizational conformism, as the employees do not want to suffer the opportunity cost of breaking routines or assume the effort of the alternative thought; and (c) it leads to lower flexibility and openness to change as a result of the "adhesion" that is finally generated to the repeated behavior (Vijande and Gonzalez, 2007). The emphasis of the continuous improvement is on incremental change developed by Imai (kaizen) aiming at process improvement (Prajogo and Sohal, 2001). Furthermore, process management focuses to guarantee the reliability of the planned and programmed tasks of the organization. The documentation and design of the processes, cleanness and preventive maintenance of the work areas are of crucial importance for the effective management of the processes (Ortiz et al.,2006). Finally the last dimension of TQM is customer focus which "is built on relationships of internal and external trust, with a view to adapting the product or service to the critical factors of quality" as indicated by Ortiz et al., (2006). Hence, TQM oriented firms should base its operations to meet or exceed the customer requirements to achieve competitive advantage where in this situation a continuous evaluation of customer orientation needs to be made (Vijande and Gonzalez, 2007).

\section{The Relation between Organizational Learning and TQM}

There appears to be no doubt about the importance of total quality management (TQM) and its positive relationship to competitiveness in terms of improved productivity and reduced costs (Sohal and Morrison, 1995). But discussions on the relationship between TQM and organizational learning do not appear very often in the literature. Essentially, only a small portion of the research regarding the concept is supported by empirical evidence or by theoretical concepts.

Enhancing competitiveness through TQM has become an increasingly important challenge for learning in organizations. Consequently organizational learning must be mentioned as a key issue, especially for organizations seeking to progress towards TQM (Martinez-Costa and Jimenez-Jimenez, 2009). According to Barrow (1993) the relationship between TQM and organizational learning has two evidences. The first evidence is that there is a cause and effect relationship, i.e. learning is an in- 
tended outcome of TQM. The second evidence is; the presence of correlation between two powerful systems - process improvement and organizational learning, which are operating in a concurrent and integrated manner. Martinez-Costa and Jimenez-Jimenez (2009) refer to Ford's (1991) consideration that TQM constitutes the environment necessary for creating organizational learning. Some authors including Senge (1994) claim that TQM is the first wave in building the learning organizations. Moreover Barrow (1993) argues that the natural outcome of TQM is the continuous improvement in quality being the accelerating vehicle for learning (Martinez-Costa and Jimenez-Jimenez, 2009). TQM is the environment where not only the single-loop learning takes place but if the organization adopts a system where workers can learn and share knowledge as well as making contributions (Martinez-Costa and Jimenez-Jimenez, 2009). Related to this fact, as a result of Hult et al.'s study in 2003; larger organizations with a longer history has a better performance in organizational learning (S.-h. Liao et al., 2008). Larger organizations having a longer history have deeper and safer quality systems. Accordingly, the TQM in such environments is created based on a double-loop learning which does not only involve trial and error but due to the vast experiences and cumulative knowledge the learning curve grows higher. The research findings indicate that organizational learning is the outcome of a successfully executed TQM processes (Martinez-Costa and Jimenez-Jimenez, 2009).

Hypothesis 2: Organizational learning has a positive influence on Total Quality Management.

\section{ORGANIZATIONAL LEARNING AND FIRM PERFORMANCE}

\section{The Relation between Organizational Learning and Firm Performance}

Related with the literature on organizational learning in relation with firm performance; organizational learning, as the source of knowledge creation and knowledge as the unique, inimitable and infinite resource of the resource-based theory, is emphasized as the factor in the achievement of competitive advantage. The literature views organizational learning as the basis of gaining a sustainable competitive advantage and a key to firm performance (Martinez-Costa and Jimenez-Jimenez, 2009). Organizations that embrace strategies consistent with the learning organization are thought to achieve improved performance (Ellinger et al, 2002; Calantone et al., 2002). Ellinger et al. (2002) examined the relationship between organizational learning and firm's financial performance. Their research aims to determine the effects of continuous learning, inquiry and dialogue, collaboration and team learning, empowerment of people towards collective vision, connection of organization to its environment and the leadership support on the financial measures of performance (e.g. ROE, ROA, MVA). Their exploratory research suggests a positive association between learning organization practices and objective measures of firms' financial performance. Additionally, Baker and Sinkula (1999) not only think that the organizational learning orientation of a firm affects its performance directly but they also think there's an indirect relationship between. A firm's learning orientation influences its performance indirectly by improving the quality of its market-oriented behaviors and directly through facilitating the generative learning that leads to innovations (Baker and Sinkula, 1999). The direct influences of organizational learning can be listed as; (1) the promotion of generative learning as a core competency as a result of knowledge creation, (2) the questioning of long-held assumptions such as to always follow market-oriented strategy, instead try to lead the market with new product development strategy for instance, (3) the realization that customer satisfaction cannot always be maximized with customer feedback mechanism but innovative disruptions are needed (Baker and Sinkula, 1999). Accordingly the learning orientation influences firm performance indirectly through market information generation and market information dissemination (Sinkula et al., 1997:307). This market information processing, is a necessary condition for organizational learning, essentially the process transforming information into knowledge (Sinkula et al., 1997: 308). Another view is that of Calantone et al.'s (2002); they think that organizational learning affects organizational performance through the firm's innovative performance (Calantone at al., 2002). Some other arguments about the positive influence of organizational learning on firm performance are stated by Martinez-Costa and Jimenez-Jimenez (2009). Organizations better at learning have a better chance of sensing events and trends in marketplace which will in turn lead to better sales and increased market share (Martinez-Costa and Jimenez-Jimenez, 2009). Moreover, organizational learning provides a more flexible and responsive structure to the organizations so that they can respond to new challenges faster than the competitors (Martinez-Costa and Jimenez-Jimenez, 2009). Continuous learning will also provide the organization fast improvement of market information processing activities (Martinez-Costa and Jimenez-Jimenez, 2009). 
Chaveerug (2008) claims that the greater commitment to learning is, the more likely that firms will achieve higher organizational performance (Chaveerug, 2008: 94). The arguments from the literature contribute to the formulation of the below hypothesis.

Hypothesis 3: Organizational learning has a positive influence on firm performance.

\section{INNOVATION AND TQM}

\section{The relation between Innovation and TQM}

The recognition of TQM as a competitive advantage cannot be underestimated around the world especially in Western countries. Together with this fact, also innovation has received considerable attention as having a crucial role in ensuring sustainable competitive advantage in the globally competitive environment (Prajago and Sohal, 2001). Almost in parallel to the calls made for organizations to become quality focused, organizations have also been urged by the researchers to become more innovative (Singh and Smith, 2004). These two determinants of firm competitive advantage can then be examined in terms of their inter-relationship in the establishment of firm performance resulting in competitive advantage. The main aims in discussing the relationship between TQM and innovation are; (1) to examine the relevance of TQM for the management of innovation; (2) to determine how useful is TQM as a resource for innovation; (3) and to clearly identify the relation between innovation and TQM (Prajago and Sohal, 2001). Another important view is that TQM is seen as one form of innovation (Prajago and Sohal, 2001). There are many common aspects of TQM and innovation (Singh and Smith, 2004). Continuous improvement is a key feature of both TQM and innovation. Open culture is seen as an important aspect of both innovation and TQM (Singh and Smith, 2004). These similarities are important due to the fact that organizations implementing TQM well could also be more innovative than organizations that do not (Singh and Smith, 2004). In other words organizations adopting TQM will posses higher innovation levels and vice versa. So TQM can be an instrument for organizations to become more innovative (Singh and Smith, 2004).

Arguments about the positive relationship between TQM and innovation focus on the idea that organizations adopting TQM in their structure create an appropriate environment for innovation in terms of growth because TQM includes principles that are in agreement with innovation (Prajago and Sohal, 2001). The continually and rapid changing customer needs, require organizations to meet these demands, fast and accurately. This goal can be achieved more successfully if new customer demands and expectations are searched and determined. So that organizations are capable of developing and introducing new products or services as innovations required for the adaptation to changing market (Prajago and Sohal, 2001). Meeting customer needs and expectations is a requirement but to make the customers delightful is the ground for competitive advantage. Hence producers or suppliers need not only to satisfy customer demands but also to exceed those needs, and that's an issue of innovation (Prajago and Sohal, 2001). Only innovating organizations can survive in this globally competitive environment keeping in mind that dynamic and responsive structure is the key factor for competitiveness. Companies adopt innovation in two ways; by copying from other firms or developing their own innovation. The second strategy is a more successful one if the competitive advantage is targeted. Companies following a TQM approach assimilate innovations imported from other firms more easily due to the willingness of its employees to accept new ideas as a result of the continuous improvement methods promoted by TQM. These enterprises can also develop their own innovations by building on the work of both continuous and breakthrough improvements (Martinez Lorente et al., 1999). According to Martinez Lorente et al. (1999) one of the main elements of TQM is the need for adequate customer focus. Since customers are going to become increasingly more demanding for the aim of identifying current and future customers and their needs, TQM constitutes a stimulus to business innovation towards a more customer oriented structure (Martinez Lorente, 1999). In line with this discussion from the literature the following hypothesis has been created.

Hypothesis 4: Total Quality Management has a positive influence on innovation.

\section{INNOVATION AND FIRM PERFORMANCE}

\section{The Relation between Innovation and Firm Performance}

The link between innovation and performance at various levels of aggregation has been the focus of attention in a number of studies in recent decades (Calantone, 2002). Nevertheless, the link between firm innovativeness and performance has not been tested sufficiently (Calantone, 2002). The ability 
of firms to satisfy customers' emerging and complex requirements, meet growing consumer expectations and satisfaction, and respond rapidly to changing environments, is largely based on their innovation orientation (Ussahawanitchakit, 2008). Innovation orientation is central to firms' survival strategy, and it becomes a potential strategy in gaining competitive advantage. An organization's openness, acceptance, and implementation of new ideas, processes, products or services and propensity to change through adopting new technologies, resources, skills and administrative systems reflect its innovation orientation, in other words its degree of being ready to innovation (Ussahawanitchakit, 2008). Innovation orientation strongly improves employees' job attitudes, job satisfaction and organizational commitment (Ussahawaniitchakit, 2008). The diffusion of innovations literature also confirms this view and suggests that firms must be innovative to gain a competitive edge in order to survive (Calantone et al., 2002). The study of Calantone et al. (2002) resulted in the positive relationship between innovativeness and firm performance. Also the findings in other studies about new product development and innovation diffusion have resulted in positive relationship between the two values. The results of the study of Calantone et al. (2002) also suggest that the competitive advantage of the firms is built on a full understanding of customer needs, competitors' actions, and technological development, an understanding made possible by organizational commitment to learning. Firms without these attributes are less likely to stand out in terms of innovation capability, although they may look elsewhere to find ways to survive (Calantone et al., 2002). These are the factors that increase business performance. Klomp and Van Leeuwen (2001) examine the relationships between the different stages of the innovation process and overall economic performance. According to their study the innovating firms perform better than the non-innovating firms, as shown in the Figure 1, indicating the growth of sales in the innovating (indicated with white bars) versus non-innovating (indicated with black bars) firms.

FIGURE 1.THE DISTRIBUTION OF SALES GROWTH OF INNOVATING VERSUS NON-INNOVATING FIRMS.

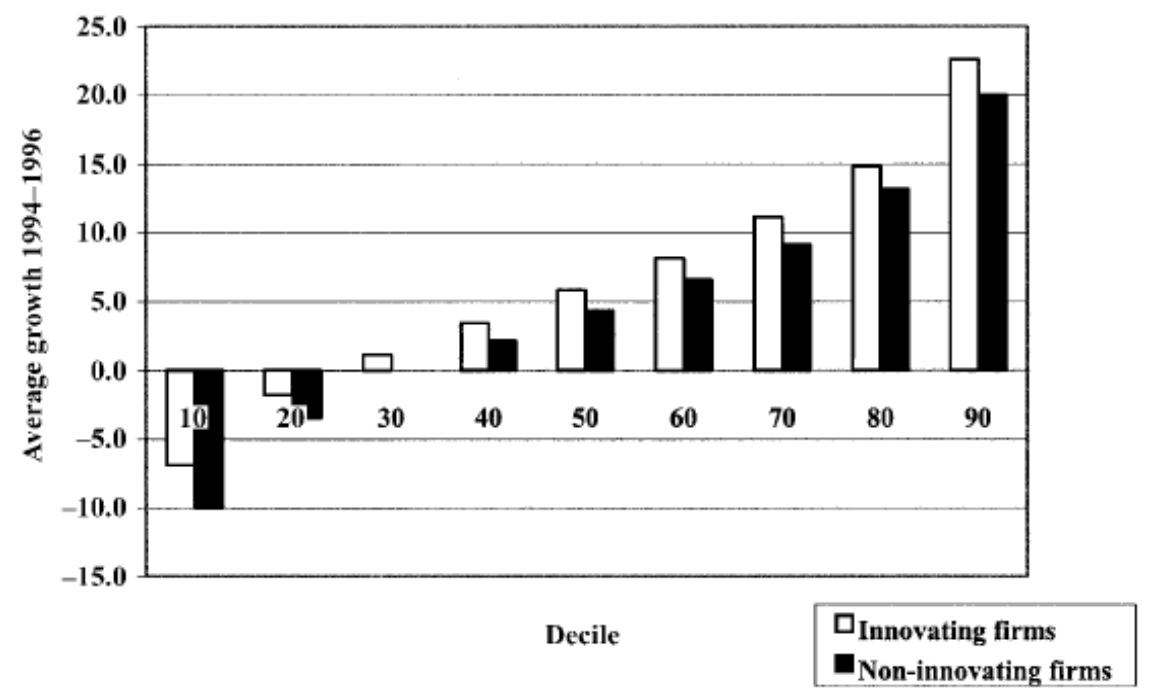

\section{Source: Klomp and Van Leeuwen, 2001.}

Recent innovation studies place much emphasis on innovation as a production process, with new or improved products as a separate output which enhances overall firm performance. This enables a firm's overall sales performance to be linked more explicitly to the innovation process (Klomp and Van Leeuwen, 2001). Klomp and Van Leeuwen conclude that the innovation contributes significantly to the overall sales performance, productivity (as measured by sales per employee) and employment growth. Darroch (2005) argues that managers wanting to enhance performance should pursue innovation since in the current environment; innovation might be required to simply remain competitive. Without innovation, firms risk losing their competitive position by falling behind (Darroch, 2005). Evidence obtained from the extensive literature research provides support for the consequent hypothesis.

Hypothesis 5: Innovations have a positive influence on firm performance. 


\section{TQM AND FIRM PERFORMANCE}

\section{The Relation between TQM and Firm Performance}

One of the most popular and most often recommended approaches to help companies improve efficiency and competitiveness through improvement of quality is the philosophy of TQM (Kumar et al., 2009: 23). The literature on quality argues that TQM is a strategy that provides organizations with competitive advantage (Martinez-Costa and Jimenez-Jimenez, 2009). The importance of quality for company's performance and success on the market is widely recognized in business literature and practice (Kumar et al., 2009). TQM implementation is believed to lead to company performance improvement. In order to study the influence of TQM on performance, an understanding of TQM is needed that enables us to identify which competencies it generates and what repercussions that has on the results (A. B. Escrig Tena et al., 2001). Numerous studies indicate positive relation between TQM implementation and performance. Examples of benefits achieved from TQM by companies around the world include: decreased inventory 23 percent in two years, order changes halved, delivery time reduced from 20 to 4.5 days, quality teams saved $\$ 5.6$ million over four years, customer claims frequency reduced by over 40 percent, customer service response time reduced by 44 percent, lost time from injuries reduced 46 percent, cost of quality reduced from 12 percent to 9 percent, operating profits increased 7.4 times, 98 percent first pass yield, on-time delivery increased from 75 percent to 99 percent, customer complaints reduced by 78 percent, $\$ 12$ million saved in one year in suggestion system, 91 percent of employees said proud to work for the company, positive responses on employee attitude survey increased from 76 percent to 83 percent (Kumar et al., 2009). Parallel with the argument of Powell (1995), A. B. Escrig Tena (2001) claims that the basic argument is that TQM can contribute to the improvement of performance by encouraging the development of assets that are specific, produce socially complex relationships, are steeped in the history and culture of the company and generate tacit knowledge. All these features correspond to the conditions, which, according to the RBV, allow a sustained competitive advantage (A. B. Escrig Tena et al., 2001). According to Powell (1995) and similarly, according to A.B. Escrig Tena (2001) TQM leads to the creation of an inimitable competitive advantage due to its production of routines and guidelines which are difficult to reproduce by the competitors. Different authors present different core competencies adopted as a result of successful application of TQM.

Researchers have concluded that TQM has a positive effect on company results (Martinez-Costa and Jimenez-Jimenez, 2009). Kaynak (2003) examines the relationships among TQM practices and the direct and indirect effects of these practices on various performance levels, Samson and Terziovsky (1999) shows this relationship in cross-sectional sense; meaning that TQM's categories of leadership, management of people and customer focus were the strongest significant predictors of operational performance and A.B. Escrig Tena et al. (2001) refers to the effects of TQM on firm competitive advantage. Research findings indicate that firm performance is an output of effectively implemented TQM practices. According to literature discussed regarding the positive relationship between TQM and organizational performance, the hypothesis to be tested can be formulated as follows:

Hypothesis 6: Total Quality Management has a positive influence on firm performance.

FIGURE 2. THE CONCEPTUAL MODEL

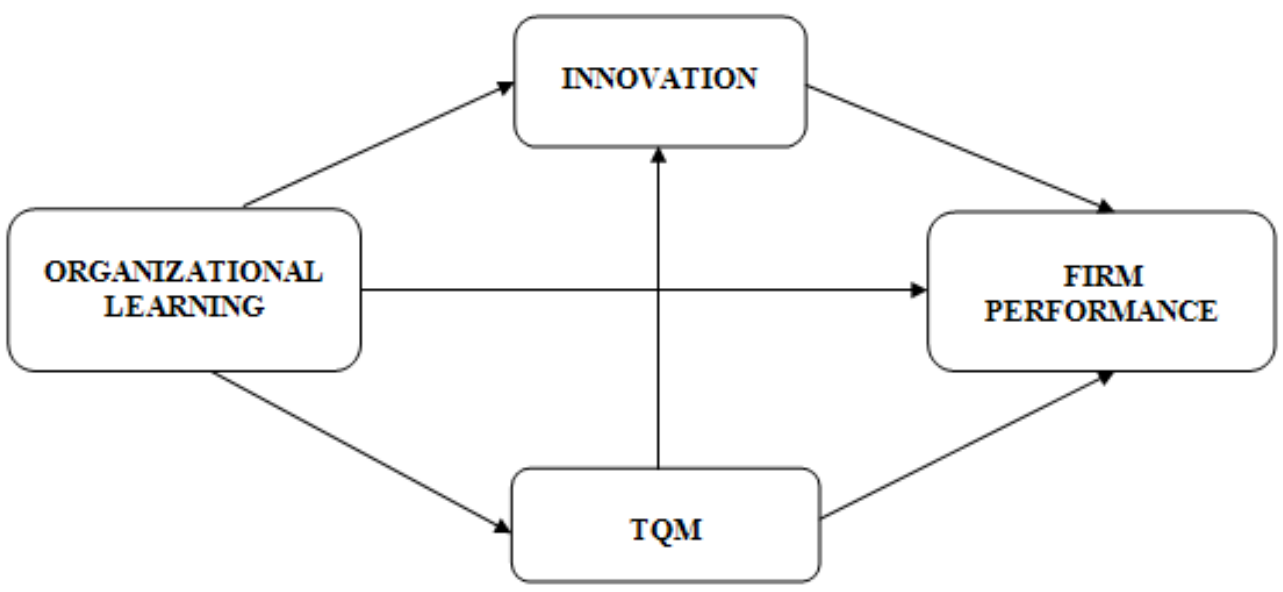




\section{RESEARCH METHOD}

\section{Sampling}

The data used to test the hypotheses are drawn from a varied spectrum of Turkey's industries. The sample frame of the study consisted of a range of industries including; telecommunications, computer and electronics, communication, software, manufacturing and machinery, chemical, service technologies, food, and material industries. The organizations taking part in the survey have both national and international, operational domains. Yet, $27 \%$ of the firms operate on a regional level, $20.2 \%$ operate on a national basis and $53.2 \%$ of the respondent firms' operational domain consists of international borders. The initial sample consisted of 185 white collar employees in 87 firms in total. The screening criterion was established on the basis that these firms which have been selected are parts of a wide range of foreign and domestic industries both in public and private sectors. The presumption that "individual views on issues will constitute a function of their organizational roles" directed the survey of the study to be done with individuals who occupy strategic positions in their organizations who would be more knowledgeable about the strategic relationships between the inter-organizational structure (Paulraj et al.,2008). Thus the use of key informants as sources of data is standard practice in strategic management research (Paulraj et al., 2008).

The survey form prepared was subject to a pilot study in the field. Regarding the warnings and suggestions analyzed through these results the survey was transmitted to more extensive masses. The general managers of the firms were contacted by telephone as a pre-notification of the survey and were announced about the immitent arrival of the survey as well as the aim of the study. Hence this involved the assurance of confidentiality and the anonymity of the responses, the data of their company or specifically products to be undisclosed and a premise that a report of the results and implications will be sent to the respondents in case they request. For the purpose of eliminating flexibility in the survey technique which would breed inconsistency and to provide a common understanding of the questions for each respondent the questions are constructed by multiple choice answers. Of the 185 contacted, 173 agreed to answer the survey. Yet, of the 173 returns, 49 were deleted due to incomplete and inconsistent information, leaving 124 usable returns for analysis. Correspondingly, from 72 out of 87 of the firms contacted, usable data was received for a response rate of $67 \%$.

\section{Measures}

The methodology consistently entails the adoption of a survey research method. A survey was conducted to validate the proposed relationships ascribed in the hypotheses and to develop a reliable discussion coextending with the findings attained. To test the hypotheses, well verified measures of multi -item scales adopted from previous studies were used. All the measurement constructs were estimated through respondents' perceptual evaluation on a seven-point Likert scale, which was anchored by the end points of "strongly disagree" (1) to "strongly agree" (7). By using the parallel translation method, the items were first translated into Turkish by one person and then translated into English by another person. The two translators then jointly reconciled all differences. Subsequently the suitability of the Turkish version of the questionnaire was pre-tested by the people working in the industry. After refining the questionnaire based on interviews with the pre-test subjects the questionnaires were then distributed and collected.

The learning dynamics in the organizations which indicate shared vision, intra-organizational knowledge sharing, commitment to learning and open mindedness are measured within the questionnaire using a scale consisting of 11 questions, developed and validated by Gomez et al., (2005). Simultaneously, concerning the evaluation of learning organizations' principles some dimensions from Chermack et al., (2006) have been adapted to survey questions. Mainly, answers for knowledge transfer, its adaptation to existing organizational culture, the encouragement of the employees' innovative ideas by top management, the involvement of the employees to the management and the favorable condition for a system based approach towards firm vision of all the employees were inquired.

An inspection on the previous empirical studies on TQM alludes that researchers have defined TQM measures in numerous ways albeit they complement each other (Prajogo and Sohal, 2006). In order to tap the domain of TQM in organizations, the scale developed by Scott et al., (2008) and Bessant et al., (2001) concerning the continuous improvement section was adopted. Besides, for the instruments captivating participation, leadership, process management and customer orientation, the scale was complemented with survey questions from the studies of Vijande and Gonzalez, (2007), Costa et al., 
(2008), Prajogo and Hong, (2008) were assigned. The five dimensions of TQM were in total measured with 19 questions which have proven to be valid and reliable instruments representing a composite indicator of TQM .

Regarding the discourse of the employees in the organization 5 questions have been identified and used reflecting the enterprise's innovation vision. In the construction process of these questions the study introduced by S. -h. Liao et al., 2008, studies of Akgün et al., (2007) and Vijande and Gonzalez et al.'s (2007) were adhered to.

Utmost, the organizational performance measurement captured the employee satisfaction and the market situation or performance of the organization. The employees were asked to answer 8 questions reflecting the essential aspects of firm performance. The measures regarding organization's market situation and performance were adopted from Law and Ngai's (2008) previously conceptualized and validated study examining the effects of intra-organizational knowledge sharing and learning behavior to the firm performance and from Lee et al., (2008). Consequently the measures assessing employee satisfaction and general organizational performance were shaped by Costa et al., (2008).

\section{Measure Validity and Reliability}

After the survey results of 124 respondents from 72 firms have been aggregated and their validity has been determined, SPSS13.00 statistical software has been utilized throughout the data analysis process.

TABLE 1. CORRELATION OF LATENT VARIABLES

\begin{tabular}{|l|l|l|l|l|l|l|l|l|l|l|l|l|}
\hline Factors & Mean & S.D. & $\mathbf{1}$ & $\mathbf{2}$ & $\mathbf{3}$ & $\mathbf{4}$ & $\mathbf{5}$ & $\mathbf{6}$ & $\mathbf{7}$ & $\mathbf{8}$ & $\mathbf{9}$ & $\mathbf{1 0}$ \\
\hline 1. Participation & 5.642 & 0.907 & 1.000 & & & & & & & & & \\
\hline $\begin{array}{l}\text { 2. Intra-organizational } \\
\text { knowledge sharing }\end{array}$ & 5.274 & 1.004 & 0.441 & 1.000 & & & & & & & & \\
\hline 3.Market Performance & 5.524 & 0.935 & 0.449 & 0.456 & 1.000 & & & & & & & \\
\hline 4. Innovation & 5.700 & 0.771 & 0.733 & 0.468 & 0.548 & 1.000 & & & & & & \\
\hline $\begin{array}{l}\text { 5.Employee } \\
\text { satisfaction }\end{array}$ & 5.693 & 0.965 & 0.682 & 0.457 & 0.572 & 0.662 & 1.000 & & & & & \\
\hline 6. Shared vision & 5.387 & 0.914 & 0.621 & 0.522 & 0.497 & 0.580 & 0.678 & 1.000 & & & & \\
\hline 7. Leadership & 5.849 & 0.954 & 0.575 & 0.489 & 0.538 & 0.569 & 0.628 & 0.593 & 1.000 & & & \\
\hline 8. Process Management & 5.847 & 0.904 & 0.436 & 0.256 & 0.332 & 0.572 & 0.361 & 0.286 & 0.529 & 1.000 & & \\
\hline $\begin{array}{l}\text { 9. Continuous } \\
\text { Improvement }\end{array}$ & 5.470 & 1.247 & 0.421 & 0.413 & 0.549 & 0.589 & 0.446 & 0.327 & 0.427 & 0.511 & 1.000 & \\
\hline $\begin{array}{l}\text { 10. Customer } \\
\text { Orientation }\end{array}$ & 6.016 & 0.770 & 0.527 & 0.434 & 0.445 & 0.565 & 0.474 & 0.479 & 0.575 & 0.596 & 0.513 & 1.000 \\
\hline
\end{tabular}

Table 1 shows the correlation among all ten variables. The relatively low to moderate correlations provided further evidence of discriminant validity. Also all reliability estimates demonstrated in Table 2 , including cronbach alphas, average variance extracted for each construct (AVE), and composite reliabilities, were well beyond the threshold levels suggested by Nunnally (1978), except the AVE's of intra-organizational knowledge sharing and innovation having average variance extracted slightly lower with 0.47 and 0.41 respectively. Furthermore, the squared correlations did not exceed the average variance extracted further suggesting discriminant validity. Concurrently, it was concluded that measures were unidimensional and had adequate reliability as well as discriminant validity. 
TABLE 2. RELIABILITY AND AVE

\begin{tabular}{|l|l|l|l|}
\hline Construct & Composite Reliability & AVE & Cronbach Alpha \\
\hline 1. Participation & 0.875414 & 0.584484 & 0.819234 \\
\hline $\begin{array}{l}\text { 2. Intra-organizational } \\
\text { knowledge sharing }\end{array}$ & 0.774331 & 0.471176 & 0.651797 \\
\hline 3. Market Performance & 0.898802 & 0.645008 & 0.861815 \\
\hline 4. Innovation & 0.845911 & 0.413297 & 0.779138 \\
\hline 5. Employee satisfaction & 0.835721 & 0.638260 & 0.674008 \\
\hline 6. Shared vision & 0.874846 & 0.585553 & 0.808036 \\
\hline 7. Leadership & 0.900106 & 0.750363 & 0.831590 \\
\hline 8. Process Management & 0.852090 & 0.658344 & 0.742760 \\
\hline 9. Continuous Improvement & 0.888435 & 0.726538 & 0.822372 \\
\hline 10.Customer Orientation & 0.876708 & 0.589406 & 0.820726 \\
\hline
\end{tabular}

Further, the measures were subject to factor analysis. When all the questions included in the survey are put through factor analysis some questions are dropped and put out of analysis because they are not in the expected factor interval. The questions that have lower than 0.5 factor values are remained out of analysis. The two dimensions of organizational learning; commitments to learning and open mindedness was not supported and were accordingly dropped after the factor analysis. The dependent and independent variables in this analysis have been considered as separate. The variables regarding organizational learning are loaded to shared vision and intra-organizational knowledge sharing; those regarding TQM are loaded to, participation, customer focus, leadership, process management and continuous improvement, finally variables regarding organizational performance are loaded to employee satisfaction and market performance as factors. Because innovation is only one factor there was no need for an additional factor analysis.

At the outset, in the section regarding general information about the organization and the respondent, nominal and serial scaling has been used. While in the nominal scaling section descriptive analysis was prevailing, in the section with likert scale questions factor analysis has been incorporated. Furthermore the impact of two or more variables on the dependent variable and the evaluation of the research hypotheses have been assessed according to the regression analysis. Reliability of a construct can be defined as the consistency and the stability of the constructs. Yet, for the estimation of internal consistency of the basic structures of the study -organizational learning, TQM, innovation, organizational performance- Cronbach Alpha value was used as suggested in the literature to be equal to or higher than 0.7 (Kerlinger, 1986). The cronbach alpha values presented in Table 2 indicate high reliability with all the constructs above 0.7 , except intra-organizational knowledge sharing (cronbach $\alpha=$ 0.65 ) and employee satisfaction (cronbach $\alpha=0.674$ ). Though, due to the high composite reliability of the items this doesn't create a major problem.

Furthermore, to test the hypotheses, we employed regression analysis and the results revealed in Table 3 . Those hypotheses are; (H1) the influence of organizational learning on innovation specifically the supported construct is; shared vision positively influences innovation in organizations, among the hypotheses involved regarding the relationship between organizational learning and TQM, (H2); shared vision positively influences participation; shared vision positively influences leadership, shared vision positively influences process management, shared vision positively influences continuous improvement, shared vision positively influences customer focus are supported. Besides, intra-organizational knowledge sharing positively influences leadership, intra-organizational knowledge sharing positively influences continuous improvement, intra-organizational knowledge sharing positively influences customer focus and intra-organizational knowledge sharing positively influences participation are the bases of the relationships between organizational learning and TQM. These results reveal that shared vision dimension of the organizational learning construct has a positive relationship with all the TQM dimensions and the intra-organizational knowledge sharing dimension of the organizational learning positively influences the four dimensions of TQM namely; leadership, continuous improvement, customer focus and participation. Furthermore, concerning the influence of organizational learning on 
firm performance (H3) the following hypotheses are supported, shared vision positively influences market performance and shared vision positively influences employee satisfaction. Which means firm performance is positively influenced by shared vision. In the $4^{\text {th }}$ hypotheses set $(\mathrm{H} 4)$, the $\mathrm{t}$-statistic values show that TQM's relationship with innovation is suggested to be relevant with values higher than 2. Those relationships are; participation positively influences innovation, process management positively influences innovation and continuous improvement positively influences innovation. Yet leadership and customer focus has no influence on innovation. Moving towards hypotheses set 5 (H5) which presents the relationship between innovation and firm performance, innovation positively influences market performance, innovation positively influences employee satisfaction, reflects that innovation positively influences firm performance. Finally the last set of hypotheses (H6) described by the relationship between TQM and firm performance reflect the positive influence of leadership on market performance and employee satisfaction, the positive relationship between participation and employee satisfaction, and that continuous improvement positively influences market performance.

TABLE 3. RESULTS

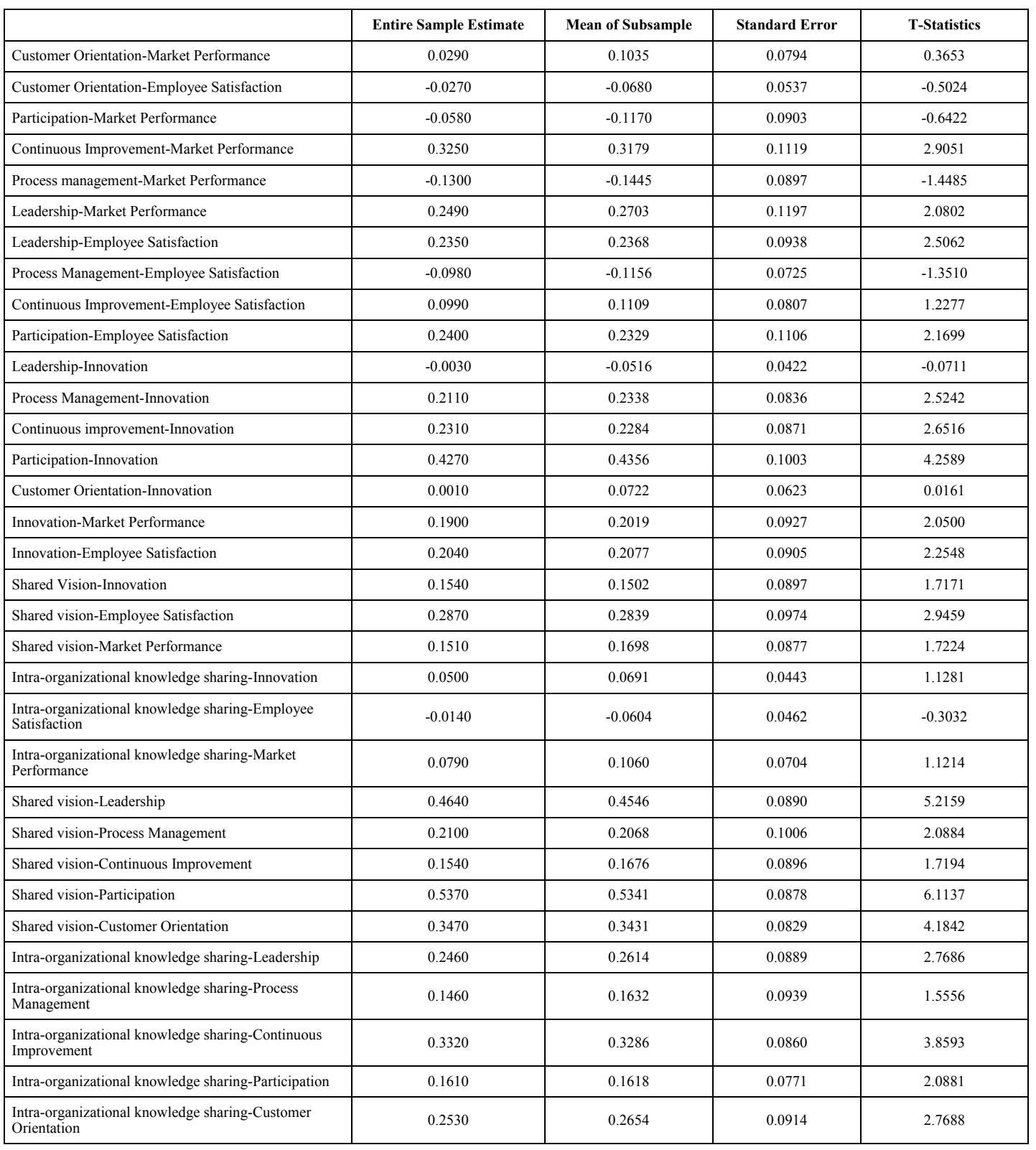


FIGURE 3. RESEARCH MODEL

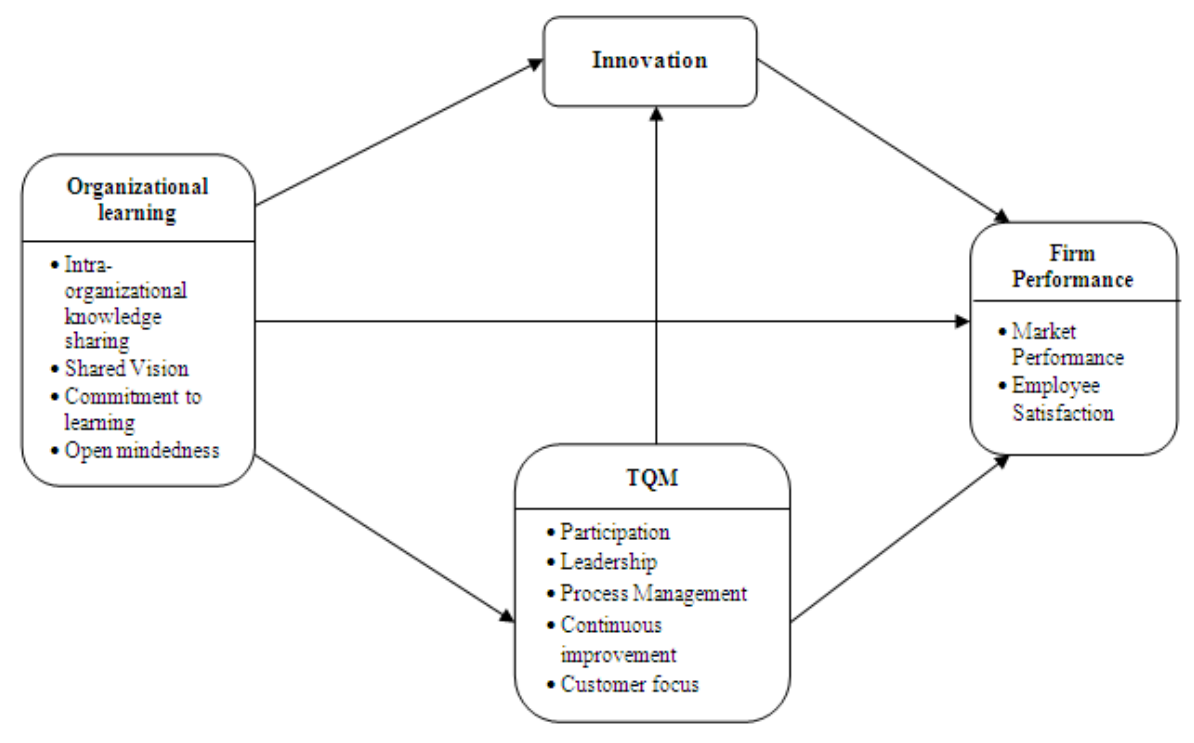

\section{CONCLUSION}

The main purpose of this study has been to explore the relationship between organizational learning, TQM, innovation and firm performance. This study develops a platform through which organizational learning shapes the strategic management of the organizations through the role of innovation and TQM for the aim of achieving improved firm performance. Significant TQM can be obtained through the role of organizational learning. Parallel to that TQM contributes to the achievement of innovation. in addition, innovation and TQM seem to have significant influence on firm performance as well as the positive relationship extracted between organizational learning and firm performance.

The findings of the study highlight the idea that, mainly organizational learning, innovation and TQM and have began to be established as legitimate and promising pivotal factors creating firm performance. Yet in the case of the emerging market of a developing country, Turkey the crucial role of intraorganizational knowledge sharing as an element of organizational learning and customer focus as a dimension of TQM have not been fully emphasized. Though the positive effect of intra-organizational knowledge sharing on TQM cannot be underestimated, its influence on innovation and firm performance seem to be minimal. Yet country profile constitutes a predictive indicator in the analysis of the results. According to a research on social values in Turkey the trust between people is very low in Turkey which results in the direction of the personal efforts to prevent any type of sharing including knowledge (Esmer, 1999). Yet customer focus is also related with the issue of trust in two ways. If the customers are not trusted enough their contribution to firm innovativeness as well as performance would be limited. Since customer focus is driven by "customer ideas and suggestions" to achieve innovation and performance, if trust lacks it results in the absence of the influencing power of customer focus on innovation and firm performance. Second, if customers don't trust the company, their contribution to processes and products will not be practical. Accordingly, it's conceived that both intraorganizational knowledge sharing and customer focus should be effectively managed for their benefit to be extracted. Concurrently, a further area to be researched appears to be "how to manage knowledge sharing and customer focus" in developing countries?" Furthermore the results of this study reveal strong positive relationship of organizational learning with TQM and firm performance. Besides, positive relationship is obtained between TQM and innovation and TQM with firm performance. Additionally innovation positively affects the two dimensions of firm performance.

Like any empirical research effort, this study contains some methodological strengths and limitations. First, there was not an industrial separation while evaluating data; results may differ for different industries. Second, there is not a separation concerning the size or the industry of the firms involved, accordingly the results may differ for SMEs and large sized organizations as well as for different industries. Third, the results reported emerge from a local area; results may differ for firms located in different areas operating in different cultural, environmental and political conditions. Despite these limitations this study provides important implications in the context of a developing country from theoretical and practical perspectives. 


\section{REFERENCES}

Akgün, Ali E.; Keskin, Halit; Byrne, John C., and Aren, Selim, (2007), Emotional and Learning Capability and Their Impact on Product Innovativeness and Firm Performance, Technovation, 27(9), pp. 501-513.

Argyris, C., and Schön, D.A. (1978), Organizational Learning: A Theory of Action Perspective, Addison-Wesley, Reading, MA.

Bessant, J., Caffyn, S., and Gallagher, M. (2001), An Evolutionary Model of Continuous Improvement Behavior, Technovation, 21(2), pp. 67-77.

Calantone, R.J., Cavusgil, S.T., and Zhao, Y. (2002), Learning Orientation, Firm Innovation Capability, and Firm Performance, Industrial Marketing Management, 31(6), pp. 515-524.

Chaveerug, A., and Ussahawanitchakit, P. (2008), Learning Orientation, Innovation Capability, and Organizational Performance in Thai Audit Firms: Moderating Effects of Organization Climate and Uncertainty Environment, Review of Business Research, 8(2), pp. 92-102.

Chermack, T.J., Lynham, S.A., and Van Der Merwe, L. (2006), Exploring the Relationship Between Scenario Planning and Perceptions of Learning Organization Characteristics, Futures, 38(7), pp. 767777.

Darroch, J. (2005), Knowledge Management Innovation and Firm Performance, Journal of Knowledge Management, 9(3), pp. 101-115.

Ellinger, A.D., Ellinger, A.E., Yang, B., Howton, S.W., Baldwin T.T., and Danielson C.C. (2002), The Relationship Between the Learning Organization Concept and Firms' Financial Performance: An Empirical Assessment (and Invited Reaction), Human Resource Development Quarterly, 13(1), pp. 529.

Hedberg, B., and Wolff, R. (2001), Organizing, Learning, and Strategizing: From Construction To Discovery, In: Dierkes, M. et. al. (Eds.): Handbook of Organizational Learning and Knowledge, Oxford/New York, pp. 535-556.

Huber, George P. (1991), Organizational Learning: The Contributing Processes and the Literatures, Organization Science, 2(1), pp. 88-115.

Hsu, Y., and Fang, W. (2009), Intellectual Capital and New Product Development Performance: The Mediating Role of Organizational Learning Capability, Technologic Forecasting and Social Change, 76(5), pp. 664-677.

Jerez-Gomez, P., Cespedes-Lorente, J., and Valle-Cabera, R. (2005), Organizational Learning Capability: A Proposal of Measurement, Journal of Business Research, 58, pp.715-725.

Kerlinger, F. N. (1986), Foundations of Behavioral Research, $3^{\text {rd }}$ Ed. New York: Holt, Reinhart and Winston.

Klomp, L., and Van Leeuwen, G. (2001), Linking Innovation and Firm Performance: A New Approach, International Journal of the Economics of Business, 8(3), pp. 343-364.

Law, C. C. H., and Ngai, E. W. T. (2008), An Empirical Study of The Effects of Knowledge Sharing and Learning Behaviors on Firm Performance, Expert Systems With Applications, 34(4), pp. 23422349.

Liao, S., Fei, W., and Liu, C. (2008), Relationship Between Knowledge Inertia, Organizational Learning and Organization Innovation, Technovation, 28, pp. 183-195.

Llorens Montes, F.J., Moreno, A.R., and Morales, V.G. (2005), Influence of Leadership and Teamwork Cohesion on Organizational Learning, Innovation and Performance: An Empirical Examination, Technovation, 25, pp. 1159-1172.

Martinez-Costa, M., and Jimenez-Jimenez, D. (2009), The Effectiveness of TQM: The Key Role of Organizational Learning in Small Businesses, International Small Business Journal, 27, pp. 98-125.

Martinez-Lorente, A., Dewhurst, F., and Dale, B. G. (1999), TQM and Business Innovation, Bradford, 2(1), pp. 12-19.

Miner, Anne, S., and Menzias, Stephen, J. (1996), Ugly Duckling No More: Pasts and Futures of Or- 
ganizational Learning Research, Organization Science, 7(1), pp. 88-99.

Nonaka, I. (1994), Understanding Strategic Learning: Linking Organizational Learning, Knowledge Management, and Sensemaking, Organization Science, 5(1), pp. 14-37.

Nonaka, I. (1995), The Knowledge Creating Company, Harvard Business Review On Knowledge Management, Harvard Business School Press, Boston, MA, 1998, pp. 21-45.

Nunnaly, J. (1978), Psychometric Theory. New York: Mcgraw-Hill.

Ortiz, P.J., Benito, G.J., and Galende, J. (2006), Total Quality Management as a Forerunner of Business Innovation Capability, Technovation, 26(10), pp. 1170-1185.

Paulraj, A., Lado, A., and Andchen, I. (2008), Inter-Organizational Communication as a Relational Competency: Antecedents and Performance Outcomes in Collaborative Buyer-Supplier Relationships, Journal of Operations Management, 26, pp. 45-64.

Prajogo, D.I., and Sohal, A.S. (2001), TQM and Innovation: A Literature Review and Research Framework, Technovation, 21, pp. 539-558.

Prajogo, D.I., and Sohal, A.S. (2006), The Integration of TQM and Technology/R\&D Management in Determining Quality and Innovation Performance, The International Journal of Management Science, 34, pp. 296-312.

Prajogo, D.I., and Hong, S.W. (2008), The Effect of TQM on Performance in R\&D Environments: A Perspective From South Korean Firms, Technovation, 28(12), pp. 855-863.

Saban, K., Lanasa, J. Lackman, C., and Peace, G. (2000), Organizational Learning: A Critical Component to New Product Development, Journal of Product and Brand Management, 9(2), pp. 99-119.

Sadler-Smith, E., Spicer, David, P., and Chaston, I. (2001), Learning Orientations and Growth in Smaller Firms, Long Range Planning, 34(2), pp.139-158.

Singh, P.J., and Smith, A.J.R. (2004), Relationship Between TQM and Innovation: An Empirical Study, Journal of Manufacturing Technology Management, 15(5), pp. 394-401.

Sinkula, J.M., Baker, W.E., and Noordewier, T. (1997), A Framework for Market-Based Organizational Learning: Linking Values, Knowledge, and Behavior, Journal of Academy of Marketing Science, 25(4), pp. 305-318.

Smith, M., and Hansen, F. (2002), Managing Intellectual Property: A Strategic Point of View, Journal of Intellectual Capital, 3(4), pp. 366-374.

Sohal, A., and Morrison M. (1995), Is There a Link Between Total Quality Management and Learning Organizations? The TQM Magazine, 7(3), pp. 41-44.

Spector, M. J., and Davidsen, P.I. (2006), How can Organizational Learning be Modeled and Measured? Evaluation and Program Planning, 29, pp. 63-69.

Subramaniam, M., and Youndt, M. (2005), The Influence of Intellectual Capital on The Types of Innovative Capabilities, Academy of Management Journal, 48(3), pp. 450- 463.

Thomas, J.B., Sussman, S.W. and Henderson, J.C. (2001), A Dynamic Theory of Organizational Knowledge Creation, Organization Science, 12 (3), pp. 331-345.

Ussahawanitchakit, P. (2008), Impacts of Organizational Learning on Innovation Orientation and Firm Efficiency: An Empirical Assesment of Accounting Firms in Thailand", International Journal of Business Research, 8 (4), pp. 1-12.

Wu, Y.-W., Chang, M.-L., and Chen, C.-W. (2006), Promoting Innovation Through the Accumulation Of Intellectual Capital, Social Capital, and Entrepreneurial Orientation, R\&D Management, 38(3), pp. 265-277 